\title{
Evaluasi Rekurensi Laparoskopi-assisted Ligasi Ekstraperitoneal dengan Penggunaan IV Catheher 18G pada Pengobatan Hernia Inguinalis Anak
}

\section{Evaluation of Laparoscopic-assisted Extraperitoneal Ligation Recurrence with the Use of $18 G$ IV Catheter in the Treatment of Pediatric Inguinal Hernias}

\author{
Septry Larissa ${ }^{1}$, Jon Efendi ${ }^{2}$, Budi Pratama Arnofyan ${ }^{3}$ \\ Fakultas Kedokteran Universitas Andalas; RSUP M. Djamil Padang, Indonesia
}

\section{ARTICLE INFO}

\section{Article history}

Received date

06 Oct 2020

Revised date

14 Oct 2020

Accepted date

21 Oct 2020

Keywords:

Laparoscopic-assisted;

IV Catheter;

Pediatric Inguinal Hernia;

Recurrence

\section{Kata kunci:}

Laparoskopi-assisted;

IV Catheter;

Hernia Inguinalis Anak;

Rekuren.

\begin{abstract}
ABSTRAK
Treatment of pediatric inguinal hernia can be done with conventional and laparoscopy methods. Laparoscopic percutaneous extraperitoneal ligation closes the internal inguinal ring by making sutures that are knotted by the extraperitoneum and implanted in the subcutaneous tissue. The rate of recurrence and postoperative complications are still a major concern. Division of pediatric surgery at Dr. M.Djamil Hospital Padang made modifications using an $18 \mathrm{G}$ intravenous catheter that was bent to form an angle of 100 150. This study aims to determine the success of laparoscopic herniotomy with modification performed by recurrence rate. This study is a retrospective analytic design method. Data was taken from the medical record status of pediatric inguinal hernia patients undergoing laparoscopic herniotomy at RSUP Dr. M.Djamil Padang from January 2018 -December 2019. Data were analyzed by crosstabulation using the Fisher test. Recurrence was seen in 7,4\% of patients (5/68 patients). Three cases in boys and 2 cases in girls. Two cases in the age group $\leq 1$ year and 3 cases in the age group $>1$ year. One case in the weight group $\leq 10 \mathrm{~kg}$ and 4 cases in the bodyweight $>10 \mathrm{~kg}$. Three recurrent cases appeared on the right side and 2 cases on the left side. There were no differences in the incidence of recurrence after laparoscopic-assisted extraperitoneal ligation with intravenous catheter $18 \mathrm{G}$ as needle puncture according to age, sex, body weight, and location of the hernia.
\end{abstract}

Pengobatan hernia inguinalis anak dapat dilakukan dengan metode konvensional dan laparoskopi. Teknik laparoskopi perkutaneus ligasi ekstraperitoneum menutup cincin inguinal interna dengan membuat jahitan yang disimpul ekstraperitoneum dan ditanam dijaringan subkutan. Angka rekurensi dan komplikasi pasca operatif masih menjadi perhatian utama. Divisi bedah anak RSUP Dr. M.Djamil melakukan modifikasi dengan menggunakan kateter intravena $18 \mathrm{G}$ yang dibengkokkan membentuk sudut $10^{\circ}-15^{\circ}$ Penelitian ini bertujuan untuk mengetahui angka keberhasilan tindakan laparoskopi herniotomi dengan modifikasi yang dilakukan dengan menilai dari rekurensi. Penelitian ini merupakan studi analitik retrospektif. Data diambil dari status rekam medis pasien hernia inguinalis anak yang menjalani tindakan laparoskopi herniotomi di RSUP Dr. M.Djamil Padang dari Januari 2018-Desember 2019. Data dianalisis dengan crosstabulasi dengan menggunakan Fisher test. Dari sampel 68 orang, didapatkan kasus rekuren pada 5 pasien (7,4\%). Tiga kasus pada anak laki-laki dan 2 kasus pada anak perempuan. 2 kasus pada kelompok usia $\leq 1$ tahun dan 3 kasus pada kelompok usia $>1$ tahun. Satu kasus pada kelompok berat badan $\leq 10 \mathrm{~kg}$ dan 4 kasus pada kelompok berat badan $>10 \mathrm{~kg}$. Tiga kasus rekuren muncul pada sisi kanan dan 2 kasus pada sisi kiri. Tidak terdapat perbedaan bermakna kejadian rekurensi pasca tindakan laparoskopiassisted ligasi ekstraperitoneum dengan menggunakan intravenous catheher $18 \mathrm{G}$ sebagai needle puncture berdasarkan usia, jenis kelamin, berat badan dan lokasi hernia.

\section{Corresponding Author:}

Septry Larissa,

Fakultas Kedokteran, Universitas Andalas Padang, Indonesia

Email: septry.larissa@gmail.com 


\section{PENDAHULUAN}

Hernia didefenisikan sebagai protrusi organ atau bagian organ melalui dinding tubuh yang normal. Hernia pada anak umumnya merupakan hernia ingunalis indirek. Hernia indirek terjadi melalui tetap terbukanya prosesus vaginalis yang menyebabkan masuknya organ visera ke area inguinal. Hernia yang terjadi bisa mencapai skrotum pada anak laki-laki tergantung derajat patennya prosesus vaginalis. Insiden tertinggi pada tahun pertama kehidupan dan meningkat selama bulan pertama. Insiden pada anak laki-laki 5-10 kali lebih sering dibandingkan anak perempuan. Hernia inguinal kanan lebih sering terjadi pada kedua jenis kelamin Angka kejadian hernia inguinal bilateral $10 \%$ pada bayi cukup bulan dan hampir 50\% terjadi pada bayi prematur dan berat badan lahir rendah.

Pengobatan merupakan poin penting karena adanya risiko komplikasi inkarserata pada usus halus, testis dan ovarium yang terjadi pada 3-16 kasus hernia inguinalis anak. Penanganan bedah pada hernia inguinalis dilakukan dengan herniotomi dan ligasi tinggi kantong hernia. Tindakan pembedahan dapat dilakukan dengan pembedahan konvensional dan baru baru ini tindakan laparoskopi sudah banyak dikembangkan pada operasi bedah anak.

Tindakan laparoskopi memiliki banyak keuntungan termasuk angka rekuren dan morbiditas yang rendah. Laparoskopi herniotomi memungkinkan untuk mengetahui adanya hernia bilateral saat operasi dan menghindari cedera pada funikulus sperma tikus. Tindakan minimal invasif dianggap lebih unggul dalam kosmetik, waktu penyembuhan, pemakaian analgetik, visualisasi anatomi, dan dapat mengeksplorasi dan memperbaiki paten prosesus vaginalis kontralateral pada saat yang sama.

Teknik laparaskopi dibagi dalam 2 kategori yaitu intraperitoneum dan ekstraperitoneum. Prinsip tindakan adalah menutup cincin inguinal interna (Hiromu, et al., 2015; Akemi, et al., 2010). Pada teknik intraperitoneum semua jahitan dan simpul dilakukan didalam rongga abdomen menggunakan instrumen laparoskopi. Pada teknik ekstraperitoneum penutupan cincin interna dengan membuat jahitan purse-string dan simpul dilakukan ekstraperitoneum kemudian ditanam di jaringan subkutan. Berbagai variasi dikembangkan dalam kedua teknik. Variasi jumlah insisi, ukuran dan jumlah trokar, instrumen, jahitan dan materi benang yang digunakan. Teknik laparoskopi ekstraperitoneum berkembang dan banyak digunakan karena dianggap lebih mudah, sederhana dan hasil yang bagus. Teknik ini dilaporkan memiliki keuntungan dibandingkan tekhnik laparoskopi tradisional dengan memungkinkan durasi operasi yang lebih singkat dibandingkan dengan teknik laparoskopi ligasi intraperitoneum. Namun angka rekurensi dan komplikasi pasca operatif masih menjadi perhatian utama pada penerapan teknik ini.

Teknik laparoskopi perkutaneus ligasi ekstraperitoneum sudah digunakan oleh divisi bedah anak RSUP Dr. M.Djamil sejak tahun 2017 dengan melakukan beberapa modifikasi. Modifikasi instrumen yang dilakukan dengan menggunakan kateter intravena $18 \mathrm{G}$ yang dibengkokkan membentuk sudut $10^{\circ}-15^{\circ}$ pada ujungnya. Penggunaan spinal needle $22 \mathrm{G}$ pada penelitian Nivash, et al. (2017) lebih sulit karena berukuran kecil dan sulit dikendalikan. Modifikasi yang dilakukan membuat teknik ini lebih mudah dan sederhana. Penelitian ini bertujuan untuk mengetahui keberhasilan teknik laparoskopi perkutaneus ligasi ekstraperitoneum dengan modifikasi yang dilakukan sebagai pengobatan hernia inguinalis anak di RSUP. Dr. M.Djamil Padang dengan melihat rekurensi pasca operatif

\section{METODE}

Penelitian ini merupakan studi analitik retrospektif terhadap pasien hernia inguinalis anak yang menjalani tindakan laparoskopi perkutaneus ligasi ekstraperitoneum di RSUP Dr. M. Djamil Padang yang dilakukan selama bulan Mei 2020 hingga Juni 2020.

Jumlah sampel minimal yang dibutuhkan dalam penelitian ini adalah 68 pasien hernia inguinalis anak yang menjalani prosedur laparoskopi herniotomi perkutaneus ligasi ekstraperitoneum. Pasien dengan data karakteristik yang tidak lengkap, pasien/keluarga pasien tidak bersedia untuk diteliti atau pasien dengan riwayat inkarserata sebelumnya dieksklusikan dari penelitian. Data karakteristik umum seperti usia, jenis kelamin, lokasi hernia, dan berat badan pasien hernia inguinalis anak dicatat untuk kemudian dianalisis. Untuk melihat pengaruh pada masing-masing variabel karakteristik terhadap angka rekurensi digunakan dengan menggunakan crosstabulasi (uji 2 beda proporsi) dengan menggunakan Fisher Exact. Nilai $p$-value $<0.05$ dianggap signifikan secara statistik.

Tindakan laparoskopi herniotomi dilakukan dengan anestesi umum. Pasien berada 
dalam posisi telentang. Operator berada pada sisi konralateral hernia. Asisten kamera berada pada sisi lainnya.

Trokar 3mm dimasukkan melalui insisi di umbilikal. Pneumoperitoneum dibuat dengan insuflasi gas CO2. Tekanan insuflasi dibuat 8$10 \mathrm{mmHg}$ dengan aliran $1-4 \mathrm{~L} /$ menit. Sebuah laparoskop dimasukkan melalui trokar umbilikal dan digunakan untuk visualisasi lapangan operasi. Posisi pasien diubah menjadi tredelenberg. Seluruh rongga peritoneum diinspeksi dan diperiksa apakah terdapat paten prosesus vaginalis kontralateral. Pergerakan instrumen dilakukan dari luar rongga abdomen dengan bantuan kamera laparoskopi.

Lokasi tusukan neddle punctre ditentukan dengan sedikit penekanan dari luar pada level cincin inguinal interna. Needle dimasukkan melalui titik puncture dan mengelilingi salah satu sisi cincin inguinal interna dan sebuah lingkaran benang dikeluarkan melalui needle. Puncture kedua melalui titik yang sama mengelilingi sisi lainnya dari cincin inguinal interna dan ujung benang dikeluarkan sehingga akan ditarik oleh lingkaran benang sebelumnya dan dikeluarkan melalui titik yang sama pada kulit. Tarikan ini menghasilkan sebuah benang yang sudah melingkari cincin inguinal interna. Benang disimpul sehingga akan menutup cincin inguinal interna secara purse-string. Simpul diletakkan pada jaringan subkutis. Luka pada umbilikal di tutup dengan benang yang diserap dengan sedikit penekanan untuk menghidari terbentuknya hematom.

Penelitian ini sudah melewati kaji etik dan mendapatkan Ethical Clearance dari Komite Etika Penelitian Fakultas Kedokteran Universitas Andalas dengan No.311/KEP/FK/2020.

\section{HASIL}

Tabel 1. Karakteristik Umum Anak dan Rekurensi Pasca Tindakan Laparoskopi Herniotomi

\begin{tabular}{|c|c|c|c|c|c|}
\hline Karakteristik Pasien & f & $\%$ & rekuren & $\%$ & \\
\hline \multicolumn{6}{|l|}{ Jenis Kelamin } \\
\hline Laki-laki & 48 & 70,6 & 3 & 6,2 & $p$-value $=0,627$ \\
\hline Perempuan & 20 & 29,4 & 2 & 10 & $\mathrm{RR}=0,625$ \\
\hline \multicolumn{6}{|l|}{ Usia } \\
\hline$\leq 1$ tahun & 23 & 33,8 & 2 & 8,7 & $p$-value $=1,000$ \\
\hline$>1$ tahun & 45 & 66,2 & 3 & 6,7 & $\mathrm{RR}=1,304$ \\
\hline \multicolumn{6}{|l|}{ Berat badan } \\
\hline$\leq 10 \mathrm{~kg}$ & 28 & 41,2 & 1 & 3,6 & $p$-value $=0,642$ \\
\hline$>10 \mathrm{~kg}$ & 40 & 58,8 & 4 & 10 & $\mathrm{RR}=0,357$ \\
\hline \multicolumn{6}{|l|}{ Lokasi Hernia } \\
\hline Unilateral & 51 & 75 & 3 & 5,9 & \\
\hline Kanan & 30 & 44,1 & 2 & 6,6 & $p$-value $=0,592$ \\
\hline Kiri & 21 & 30,9 & 1 & 4,7 & $\mathrm{RR}=0,500$ \\
\hline Bilateral & 17 & 25 & 2 & 11,8 & \\
\hline \multicolumn{6}{|l|}{ Hernia Rekuren } \\
\hline Rekurensi & 5 & 7,4 & & & \\
\hline Tidak Ada Rekurensi & 63 & 92,6 & & & \\
\hline
\end{tabular}

Dari tabel 1 didapatkan bahwa pasien lakilaki lebih banyak $(70,6 \%)$ dibandingkan pasien perempuan $(29.4 \%)$. Penderita hernia inguinalis pada kelompok usia >1 tahun lebih banyak $(66,2 \%)$ dibandingkan dengan pasien anak berusia $\leq 1$ tahun $(33,8 \%)$. Persentase anak penderita hernia inguinalis yang memiliki berat badan $>10 \mathrm{~kg}(58,8 \%)$ lebih besar dibandingkan dengan anak yang memiliki berat badan $\leq 10 \mathrm{~kg}$
$(41,2 \%)$. Kasus hernia inguinalis bilateral ditemukan pada 17 kasus (25\%) dan unilateral ditemukan pada 51 kasus (25\%). Hernia lebih banyak ditemukan pada sisi kanan 30 kasus $(44,1 \%$,) dan sisi kiri 21 kasus $(30,9 \%)$. Kejadian hernia rekuren pada sisi yang sama setelah 6 bulan pasca tindakan laparaskopi herniotomi sebesar 7,4\% (5 kasus). 
Tabel 1. Insiden Rate Hernia Rekuren

\begin{tabular}{clrlrr}
\hline Pasien & Hasil rekurensi & Person time (bulan) & Insidens & Total person time & Insiden rate \\
\hline 1 & Rekurensi & 6 & & & \\
2 & Rekurensi & 6 & & & \\
3 & Rekurensi & 7 & & & \\
4 & Rekurensi & 12 & $=7,4 \%$ & & \\
5 & Rekurensi & 12 & & & \\
6 & Tidak rekurensi & 0 & & & \\
\hline
\end{tabular}

\section{Survival Functions}

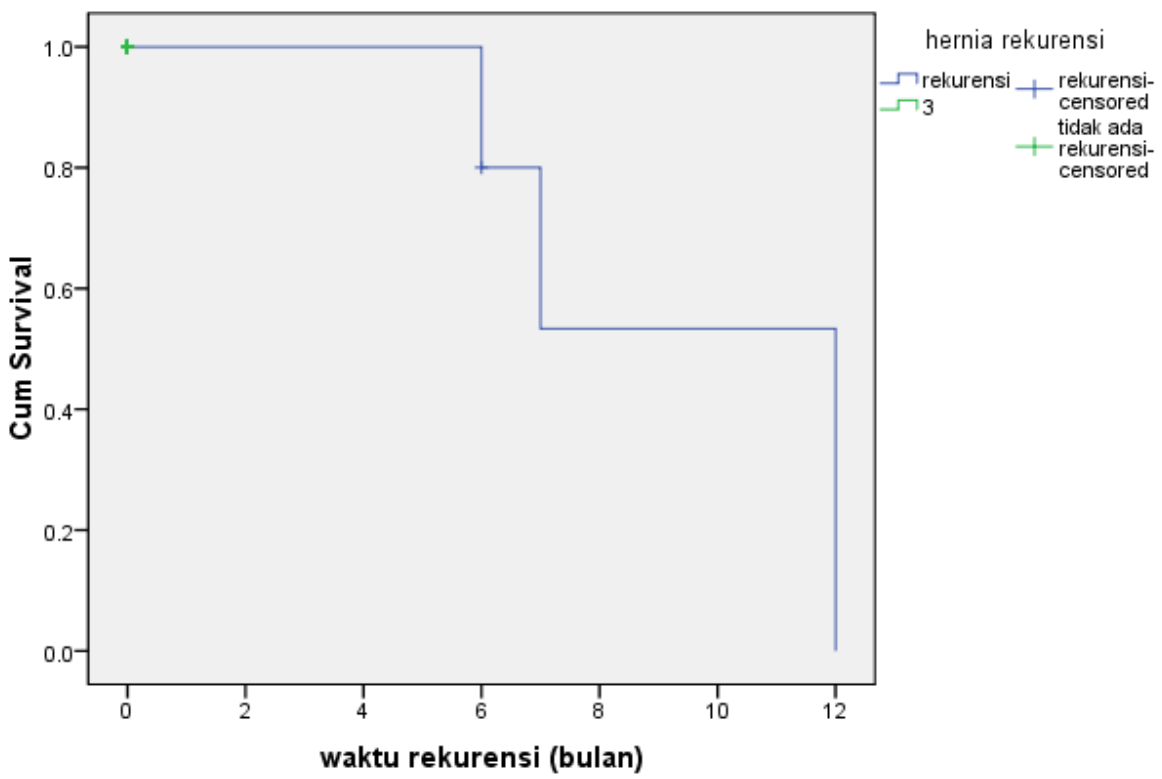

\section{Gambar 1. Kurva Rekurensi Tindakan Laparaskopi Herniatomi Perkutaneus Ligasi Ekstraperitoneum.}

Tabel 2 dan gambar 1 menjelaskan insiden rate kasus rekuren pasca laparaskopi herniotomi perkutaneus ligase ekstreperitoneum pada penelitian ini. Didapatkan bahwa frekuensi kasus hernia rekuren pasca tindakan laparaskopi herniotomi perkutaneus ligasi ekstraperitonium selama kurun waktu 1 tahun adalah sebesar 0,14 kali.

Berdasarkan kelompok usia, didapatkan 2 kasus rekurensi dari $23(8,7 \%)$ pasien anak kelompok usia $\leq 1$ tahun dan 3 kasus dari 42 $(6,7 \%)$ pasien anak kelompok usia $>1$ tahun, namun tidak terdapat perbedaan yang signifikan kejadian rekurensi antara kelompok usia $\leq 1$ tahun dengan kelompok usia $>1$ tahun ( $p$-value $=1,000$; $\mathrm{RR}=1,304$ ).

Hasil analisis hubungan antara jenis kelamin menunjukkan sebanyak 3 dari $48(8,7 \%)$ pasien anak laki-laki dan 2 dari $20(10 \%)$ pasien anak perempuan mengalami rekurensi setelah dilakukan tindakan laparaskopi herniotomi perkutaneus ligasi ekstraperitoneum, namun tidak ada perbedaan yang signifikan pada kejadian rekurensi antara pasien anak laki-laki dengan pasien anak perempuan ( $p$-value $=0,627$; $\mathrm{RR}=0,625$ ).
Berdasarkan berat badan, diperoleh sebanyak 1 dari $28(3,6 \%)$ pasien anak dengan berat badan $\leq 10 \mathrm{~kg}$ dan 4 dari $40(10 \%)$ orang pasien anak dengan kelompok berat badan $>10 \mathrm{~kg}$ mengalami rekurensi setelah dilakukan tindakan laparoskopi herniotomi perkutaneus ligasi ekstraperitoneum. Tidak ditemukan perbedaan angka rekuensi yang signifikan antara kelompok berat badan $\leq 10 \mathrm{~kg}$ dengan pasien anak kelompok berat badan $>10 \mathrm{~kg}$ ( $p$-value $=0,642 ; \mathrm{RR}=0,357$ ).

Berdasarkan lokasi hernia inguinal, diperoleh sebanyak 3 dari 51 (5,9\%) kasus hernia inguinal unilateral dan 2 dari $11(11,8 \%)$ kasus hernia inguinal bilateral mengalami rekurensi. Hasil uji statistik menunjukkan tidak terdapat perbedaan kejadian rekurensi dengan lokasi hernia inguinalis setelah dilakukan tindakan laparoskopi herniotomi perkutaneus ligasi ekstraperitoneum $(p$-value $=0,592 ; \mathrm{RR}=0,500)$

Kejadian hernia rekuren yaitu hernia yang timbul lagi pada sisi yang sama setelah 6 bulan pasca tindakan laparaskopi herniotomi sebesar 7,4\% (5 kasus), yaitu 4 kasus rekuren pada sisi kanan, 1 kasus pada sisi kiri dan tidak terdapat kasus hernia rekuren bilateral. 


\section{PEMBAHASAN}

Penelitian ini dilakukan terhadap 68 anak yang menderita hernia inguinalis yang menjalani tindakan laparoskopi herniotomi perkutaneus di RSUP Dr. M.Djamil Padang tahun 2018-2019. Divisi bedah anak RSUP Dr. M.Djamil melakukan modifikasi berupa penggunaan satu trokar untuk sebuah laparoskopi yang membantu visualisasi lapangan pandang, instrumen kateter intravena $18 \mathrm{G}$ sebagai needle puncture, benang non-absorbable 3-0 untuk melakukan ligasi cincin inguinal interna dan teknik ligasi ekstraperitoneum.

Teknik laparoskopi memungkinkan untuk melakukan ligasi cincin inguinal interna lebih proksimal dibandingkan pada teknik herniotomi terbuka sehingga mencegah terjadinya rekuren. Obliterasi dan jaringan ikat yang terbentuk akan menutup cincin interna. Ligasi komplit dari cincin inguinal interna merupakan faktor penting dalam mencegah munculnya hernia rekuren. Namun kejadian rekuren masih dilaporkan pasca tindakan laparoskopi herniotomi.

Angka rekurensi pada prosedur laparoskopi dilaporkan mencapai $4 \%$. Penyebab utama pada fase awal dianggap adalah faktor teknik dan masih rendahnya pengalaman ahli bedah sebagai operator. Kantong hernia yang tidak didiseksi pada sebagian besar tekhnik laparoskopi menjadi faktor penting dalam kejadian rekuren dan hidrokel post operatif. Pada operasi elektif resiko rekurensi hanya terjadi pada $1 \%$ kasus. Faktor resiko meningkatkan kasus hernia rekuren adalah prematuritas, hernia inkarserata, penyakit penyerta seperti gangguan jaringan ikat, VP shunt, kantong hernia tidak diligasi dengan baik sehingga masih menyisakan defek, robekan kantong hernia atau dinding posterior kantong dan cincin interna cukup lebar.

Kasus rekurensi ditemukan pada 5 pasien dari total sampel 68 orang. Angka rekurensi mencapai $7,4 \%$. Angka ini lebih tinggi dari penelitian yang dilakukan oleh Miyake, et al. (2018) yaitu 0,48\%. Miyake, et al. (2018) mengumpulkan data 1530 pasien hernia yang dilakukan tindakan laparoskopi perkutaneus ligasi ekstraperitoneum dari tahun 2008-2015 dan menemukan 8 kasus rekuren. Studi oleh Esposito, et al. (2016) menemukan angka rekurensi pada kelompok hernia terbuka dengan rentang 0-5\% dan $0-5,5 \%$ pada kelompok laparoskopi. De lange D.H, et al (2010) menyimpulkan dalam studinya bahwa insiden rekuren dalam 1 tahun pertama setelah operasi cukup tinggi yaitu $1,8 \%$. Rentang tahun penelitian yang lebih singkat dari 2018-2019 karena teknik laparoskopi baru mulai digunakan pada tahun 2017 menyebabkan jumlah sampel sedikit pada penelitian ini.

Dua kasus rekurensi dari $23 \quad(8,7 \%)$ pasien anak kelompok usia $\leq 1$ tahun dan 3 kasus dari $42(6,7 \%)$ pasien anak kelompok usia $>1$ tahun, namun tidak terdapat perbedaan yang signifikan kejadian rekurensi antara kelompok usia $\leq 1$ tahun dengan kelompok usia $>1$ tahun ( $p$-value $=1,000 ; \quad \mathrm{RR}=1,304) . \quad$ Studi yang dilakukan Masahiro, et al. (2018) mendapatkan 1 kasus rekuren dari $120(0,83 \%)$ anak yang menjalani tindakan laparoskopi herniotomi dan 2 dari $82(2,4 \%)$ anak yang menjalani herniotomi terbuka pada usia $<6$ bulan. Kantong hernia yang tipis menjadi penyulit saat melakukan herniotomi terbuka pada anak dan neonatus sementara tindakan laparoskopi memungkinkan mencapai cincin inguinal interna tanpa harus melakukan diseksi pada kanalis inguinalis. Teknik sederhana pada laparoskopi perkutaneus ligasi ekstraperitoneum menjadi alasan durasi operasi menjadi lebih singkat dan angka rekurensi yang rendah.

Koichiro, et al. (2015) menyimpulkan tindakan laparoskopi perkutaneus ligasi ekstraperitoneum aman dan efektif dilakukan pada neonatus dan anak usia $<1$ tahun. Kasus rekuren ditemukan pada 1 dari 150 anak $<1$ tahun dan 1 kasus dari 607 anak $>1$ tahun. Penelitian Miyake, et al. menyimpulkan usia $<12$ bulan merupakan faktor resiko hernia rekuren pasca laparoskopi perkutaneus ligasi ekstraperitoneum $(2,5 \%, p$-value $=0,04)$. Peritoneum pada anak usia $<1$ tahun tipis sehingga mudah robek dan terlewatkan sehingga skip area yang muncul memicu terjadinya hernia rekuren. Struktur kantong hernia dan organ sekitar yang masih rapuh, lapangan operasi yang sempit dan proporsi organ saluran cerna di dalam rongga peritoneum yang cukup besar akan menimbulkan kesulitan saat melakukan tindakan laparoskopi herniotomi perkutaneus ligasi ekstraperitoneum pada neonatus dan bayi.

Kasus rekuren ditemukan pada kedua kelompok jenis kelamin. Angka rekurensi pada kedua jenis kelamin ini adalah 6,2\% (3 dari 48 anak laki-laki) dan 10,0\% (2 dari 20 anak perempuan). Hasil uji statistik menunjukkan tidak terdapat hubungan bermakna antara jenis kelamin dan kejadian rekurensi $p$-value $=0,627$. Hasil analisa statistik menunjukkan anak laki-laki mempunyai peluang 0,6 kali $(\mathrm{RR}=0,625)$ mengalami rekurensi pasca tindakan laparoskopi herniotomi perkutaneus ligasi ekstraperitoneal dibandingkan anak perempuan.

Hasil penelitian ini sejalan dengan penelitian Miyake, et al, (2018) yang 
menemukan 8 kasus rekuren pada kelompok jenis kelamin laki-laki ( $p$-value $=0,01)$. Treef (2009) menemukan 32 kasus rekuren dengan perbandingan laki-laki dan perempuan 26:6. Perbedaan anatomi dan tekhnik dalam operasi antara kedua jenis kelamin menjelaskan perbedaan rekurensi pada kedua jenis kelamin. Pentingnya ligasi komplit dari cincin interna mencegah munculnya hernia rekuren. Pembuluh darah testikular dan funikulus spermatikus yang harus dihindari saat melakukan diseksi dan ligasi peritoneum pada cincin inguinal internal memungkinkan adanya peritoneum yang terlewatkan (gap peritoneum) atau skip area. Skip area yang muncul menjadi titik lemah yang memicu terjadinya hernia rekuren.

Satu kasus rekuren $(3,6 \%)$ ditemukan dari 28 anak kelompok berat badan $\leq 10 \mathrm{~kg}$ dan 4 kasus rekuren $(10 \%)$ dari 40 anak kelompok berat badan >10kg. Hasil uji statistik menunjukkan tidak terdapat hubungan bermakna antara kelompok berat badan $\leq 10 \mathrm{~kg}$ dengan kelompok berat badan $>10 \mathrm{~kg}$ dengan kejadian rekurensi ( $p$-value $=0,642)$. Hasil analisa statistik menunjukkan anak dengan kelompok berat badan $\leq 10 \mathrm{~kg}$ mempunyai peluang 0,3 kali $(\mathrm{RR}=0,357)$ mengalami rekurensi pasca tindakan laparoskopi herniotomi perkutaneus ligasi ekstraperitoneal dibandingkan anak kelompok berat badan $>10 \mathrm{~kg}$.

Hasil penelitian ini berbeda dengan penelitian Miyake, et al. (2018) yang menemukan 5 dari 8 kasus rekurensi memiliki berat badan $<10 \mathrm{~kg}$ ( $p$-value $=0,16)$. Miyake, et al. (2018) menyimpulkan usia $<1$ tahun, berat badan $<10 \mathrm{~kg}$, unilateral dan pengalaman operator menjadi kandidat faktor resiko yang mempengaruhi terjadinya hernia rekuren pasca tindakan laparoskopi herniotomi perkutaneus ligasi ekstraperitoneum. Salmai, et al. (2011) menyimpulkan dalam studinya tindakan laparoskopi herniotomi pada anak dengan berat badan $<5 \mathrm{~kg}$ aman, mudah dan angka rekurensi lebih rendah dibandingkan dengan herniotomi terbuka $(2,0 \%$ vs $2,7 \%)$. Perbedaan pada penelitian ini bisa disebabkan oleh jumlah sampel yang sedikit dan keberadaan faktor lain yang juga mempengaruhi kejadian rekurensi pada penelitian ini.

Pada penelitian ini terdapat tiga dari 51 $(5,9 \%)$ kasus hernia inguinalis unilateral yang dilakukan tindakan laparokopi herniotomi perkutaneus ligasi ekstraperitoneum mengalami rekuren. Sedangkan pada kasus hernia inguinalis bilateral terjadi 2 kasus rekuren dari 11 kasus hernia inguinal bilateral yang menjalani tindakan laparoskopi herniotomi perkutaneus ligasi ekstraperitoneum. 4 kasus rekuren pada sisi kanan, 1 kasus pada sisi kiri dan tidak ada kasus hernia rekuren bilateral

Hasil uji statistik menunjukkan tidak terdapat hubungan bermakna antara kelompok hernia inguinal unilateral dan kelompok hernia inguinal bilateral dengan kejadian rekurensi $p$ value $=0,592$. Hasil analisa statistik menunjukkan kelompok hernia inguinal unilateral mempunyai peluang 0,5 kali $(\mathrm{RR}=0,500)$ mengalami rekurensi pasca tindakan laparoskopi herniotomi perkutaneus ligasi ekstraperitoneum dibandingkan kelompok hernia inguinal bilateral. Hasil studi ini sejalan dengan dengan penelitian yang Rafik, et al. (2017) mendapatkan 70 kasus hernia rekuren pada sisi kanan, 43 kasus hernia rekuren pada sisi kiri dan tidak terdapat hernia rekuren bilateral. Studi Miyake, et al. (2018) mendapatkan 5 kasus rekuren pada sisi kanan dan 3 pada sisi kiri ( $p$-value $=0,85)$. Tindakan laparoskopi memungkinkan eksplorasi dan tindakan pada sisi kontralateral pada waktu yang sama sehingga kejadian rekuren pada kedua sisi jarang dilaporkan.

Tidak adanya perbedaan bermakna kejadian rekurensi pada kelompok usia, jenis kelamin, berat badan dan lokasi hernia pada penelitian ini dipengaruhi oleh keterbatasan jumlah sampel dan keberadaan faktor lain yang mempengaruhi munculan rekurensi pasca tindakan laparoskopi herniotomi perkutaneus ligasi ekstraperitoneum. Faktor lain tersebut antara lain faktor operator, teknik jahitan, dan jenis benang yang digunakan.

Kejadian hernia rekuren dipengaruhi kontribusi berbagai faktor. Variasi material, teknik operasi, dan teknik penjahitan cincin inguinal interna dianggap berperan dalam munculnya hernia rekuren. Kegagalan melakukan ligasi tinggi pada kantong hernia, jahitan tension pada cincin inguinal interna, defek hernia yang besar, jahitan purse string lepas, skip area terutama di atas vas deveren dan pembuluh darah gonadal, hematom dan keterbatasan pengalaman ahli bedah dipertibangkan dalam munculnya hernia rekuren.

Tekhnik jahitan dan simpul sebisa mungkin mengurangi munculnya skip area dan jahitan yang thigh dapat mencegah munculnya hernia rekuren, menghindari jahitan terlalu ketat, simpul yang kedap udara dan melakukan stresstest dapat mengurangi munculnya rekuren pasca tindakan laparoskopi pada semua usia.

Material yang digunakan untuk ligasi cincin inguinal interna dipertimbangkan sebagai faktor resiko. Grimsby, et al. (2015) mendapatkan angka rekurensi pada penggunaan polyester $4 \%$ dan $27 \%$ polyglactin terhadap 97 
orang pasien yang menjalani tindakan laparoskopi perkutaneus ligasi.

Pengalaman dan kemampuan ahli bedah akan mempengaruhi outcome. Jyoji (2013) menuliskan untuk mendapatkan keahlian yang bermakna dibutuhkan melakukan 30 tindakan laparoskopi perkutaneus ligasi ekstraperitoneal. Sehingga 30 kasus pertama yang dikerjakan seorang ahli bedah mempunyai resiko menjadi hernia rekuren.

Louati, et al. (2018) menyimpulkan Teknik Laparoskopi-assisted ligasi ekstraoeritoneal dapat diterapkan sebagai alternatif tindakan operasi konvensional dengan mempertimbangkan tingkat rekurensi masing-masing tekhnik.

\section{DAFTAR PUSTAKA}

Akemi Lk, E. S. (2010). Inguinal hernias and hydrocele. In : Chung, Chen. Atlas of pediatric Surgical techniques. china: elsevier saunders.

De lange DH, K. M. (2010). Inguinal hernia surgery in netherlands : are patients treated according to the guidelines? Hernia 143148.

Esposito, C., Escolino, M., Turrà, F., Roberti, A., Cerulo, M., Farina, A., ... \& Settimi, A. (2016, August). Current concepts in the management of inguinal hernia and hydrocele in pediatric patients in laparoscopic era. In Seminars in pediatric surgery (Vol. 25, No. 4, pp. 232-240). WB Saunders.

Grimsby, G. M. (2015). Non-absorbable sutures are associated with lower recurrence rates in laparoscopic percutaneous inguinal hernia ligation. . journal of Pediatric urology, 275-e1.

Hiromu M, K. F. (2015). comparison of percutaneus extraperitoneal closure ( LPEC ) and open repair for pediatric inguinal hernia : experience of a single institution with over 1000 cases. Surg Endosc .

Hiroo U, H. K. (2010). Inguinal hernia repair in children using single-incision laparoscopic-assisted percutaneus extraperitoneal closure . Journal of pediatric surgery.

Jyoji Y, S. A. (2013). Laparaoscopic Percutaneus extraperitoneal closure for inguinal hernia : learning curve for attending surgeons and residents . Pediatric surgery int. Springer.

\section{SIMPULAN}

Tidak terdapat perbedaan bermakna kejadian rekurensi pasca tindakan laparoskopi herniotomi perkutaneus ligasi ekstraperitoneum berdasarkan kelompok usia, jenis kelamin, berat badan, maupun lokasi hernia. Diharapkan adanya registrasi khusus untuk pasien anak dengan hernia inguinalis sehingga dapat diikuti follow up tentang komplikasi dan keberhasilan tindakan yang dilakukan. Penelitian metaanalisis lanjutan yang menggabungkan hasil penelitian berbagai center sehingga angka keberhasilan serta faktorfaktor yang mempengaruhi dapat diketahui akan sangat dibutuhkan.

Koichiro Y, Y. K. (2015). The safety and efficacy of laparoscopic Percutaneus extraperitoneal closure for inguinal hernia in neonates and infant younger than 1 year of age in comparixon to older patients. Journal of laparoendoscopic \& advance surgical techniques.

Louati, H., Jallouli, M., Zouari, M., Zitouni, H., Ben Dhaou, M., \& Mhiri, R. (2018). Laparoscopic-Assisted Percutaneous Extraperitoneal Closure for Inguinal Hernia Repair in Children: An Initial Experience. International Journal of Pediatrics, 6(8), 8039-8046.

Masahiro Z, R. S. (2018). Safety and efficacy of laparoscopic Percutaneus extraperitoneal closure for inguinal hernia in infant younger than 6 months : a comparison with conventional open repair. Asian Journal of Endoscopic Surgery .

Miyake, K. F. (2017). Risk Factor for recurrence and contralateral inguinal hernia after laparoscopic percutaneous extraperitoneal closure for pediatric inguinal hernia. . Journal of pediatric surgery, 317 -321.

Nivash S, S. R. (2017). Congenital Inguinal Hernia Laparoscopic Percutaneous Extracorporeal Closure (Lpec) By A Spinal Needle Vs Open Herniotomy Surgery. Journal of dental and medical Science.

Rafik, M. r. (2017). Fifteen years experience with laparoscopic inguinal hernia repair in infant and children . Journal of laparoendoscopic \& advance surgical technique . 
Salmai T, J. E. (2011). Laparoscopic inguinal herniorrhaphy in babies weighing $5 \mathrm{~kg}$ or less. Surg Endosc.
Treef, W., \& Schier, F. (2009). Characteristics of laparoscopic inguinal hernia recurrences. Pediatric surgery 